\title{
AS PAISAGENS DO RIO CAPIBARIBE NO SÉCULO XIX E SUAS REPRESENTAÇÕES ${ }^{1}$
}

\author{
LANDSCAPES OF THE RIVER CAPIBARIBE IN THE $19^{\text {TH }}$ CENTURY AND THEIR \\ REPRESENTATIONS
}

\section{MELO, Vera Mayrinck}

Arquiteta, doutora em Geografia Humana/UFRJ e professora adjunta do Departamento de Arquitetura e Urbanismo da UFPE.

Email:veramelo@hotlink.com.br

\section{RESUMO}

Este texto enfoca a formação das paisagens do rio Capibaribe durante o século XIX, através das representações feitas pelos viajantes nos seus relatos. Este período foi marcado por grandes transformações nas paisagens do Recife e do rio Capibaribe, que aqui serão narradas de forma conjunta, considerando que esse rio contribuiu como elemento marcante na construção e estruturação dessa cidade. A inter-relação de ambos não ocorre apenas por serem uma unidade geográfica, mas por estarem vinculados por fatores, histórico, econômico e social. As transformações decorrentes da ação do homem ao longo desse período histórico, num processo de construção social, resultaram em paisagens repletas de significados. É através das representações retratadas nas iconografias e nos relatos desses viajantes, que se constituem produtos culturais, que ficará evidenciado a formação destas paisagens e o seu significado para aqueles que a construíram, vivenciaram e usufruíram neste período.

Palavras-chave: Paisagem cultural, representação, transformação.

\begin{abstract}
This paper focuses on the formation of landscapes of the river Capibaribe during the $19^{\text {th }}$ century based on the representations made of them by travelers in their accounts. This period was marked by great transformations in the landscapes of Recife and of the river Capibaribe, which will be discussed here together, since this river contributed so much to the construction and structuring of this city. The inter-relationship of city and river does not only come about because they form a single geographical unit but because they are linked by other factors, namely historical, economic and social. The transformations brought about by the action of man throughout this historical period, in a process of social construction, resulted in landscapes full of meanings. It is through the representations depicted in the iconography and accounts of travelers, that cultural products are formed, and that evidence will be found of how these landscapes were formed and what meanings they had for those who built, experienced and made use of them in this period.
\end{abstract}

Key words: Cultural landscape, meanings, representation.

\section{Introdução}

O rio Capibaribe contribuiu como elemento marcante na construção e na estruturação da cidade do Recife $^{2}$ (Figuras 1e 2), estando tão intimamente vinculado à sua história, que a inter-relação de ambos não ocorre apenas, segundo Chacon (1959, p. 9) como "uma unidade geográfica, histórica, econômica e sociológica, mas também sentimental e poética".

As transformações decorrentes da ação intencional do homem sobre o sítio do Recife e esse rio, num processo de construção social ao longo da história, resultaram nas paisagens atuais, compostas por diversas camadas de significados. A abordagem de paisagem aqui adotada parte do entendimento de que estas paisagens são expressões de diferentes culturas. 


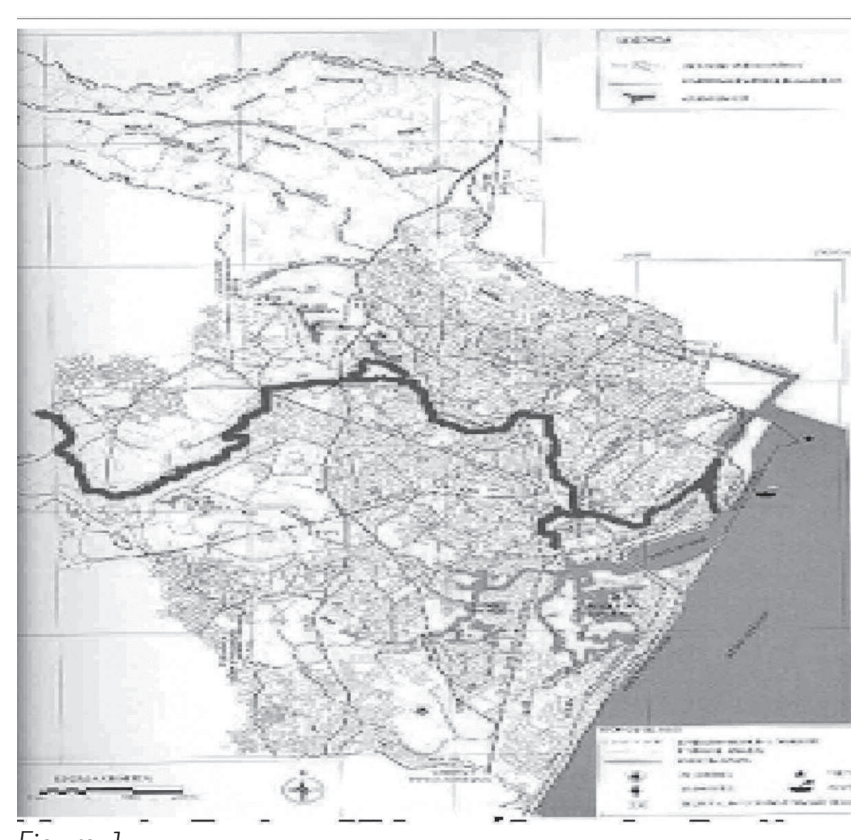

Figura 1

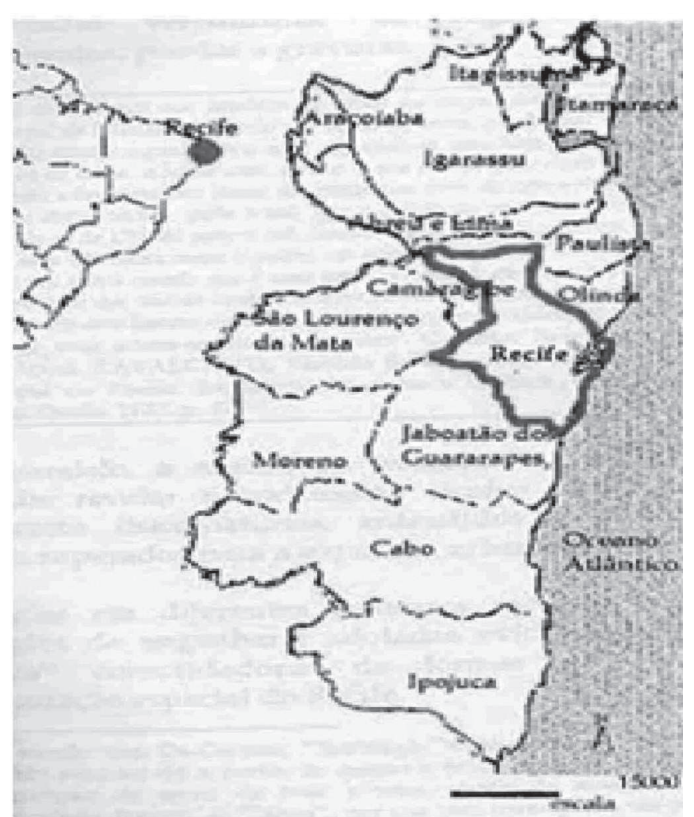

Figura 2

Durante esse processo, essas paisagens inspiraram as mais diversas representações, revelando a multiplicidade de significados que delas emanam. É nesse contexto que, através das representações retratadas em iconografias e nos relatos de viajantes, será narrada ${ }^{3}$ a formação da cidade do Recife e os significados que tiveram, ao longo desse período histórico, as paisagens do rio Capibaribe e da cidade do Recife, tanto para os que a construíram, vivenciaram e usufruíram, como para os viajantes, que as contemplaram, admiraram e exploraram.

\section{Século XIX - Representações das paisagens do rio Capibaribe pelos relatos dos viajantes}

O século XIX foi um período marcado por grandes transformações na paisagem do Recife, tanto na urbana como nos seus arredores. Isso ocorreu a partir da abertura dos portos às nações amigas, em 1808, integrando o Brasil no circuito do comércio internacional, rompendo assim o monopólio comercial com Portugal.

Os viajantes estrangeiros de diversas nacionalidades que à cidade chegaram não tinham apenas interesses comerciais, financeiros ou industriais, mas também científicos e artísticos.

Muitos desses viajantes, eram artistas amadores, colecionadores e naturalistas, vindo em expedições financiadas por instituições de seus países de origem, com o intuito de observarem e fornecerem informações para que os europeus, a partir das "maneiras de ver" desses observadores, formulassem uma imagem "típica" da paisagem dos trópicos (LIMA, 2001, p. 12).

Assim, a partir do relato dos viajantes que desembarcaram no Recife nesse período, é que poderemos interpretar os significados que teve a paisagem da cidade do Recife e do rio Capibaribe para os mesmos, através das representações contidas nos seus diários e anotações. Esses relatos devem ser lidos como registros "simbólicos" de grande valor, representando o ato de esses viajantes trilharem esses terrenos, observarem essas paisagens e descrevê-las.

Logo após a abertura dos portos, em 1809, chegou ao Recife, vindo da Inglaterra, Henry Koster 4 , publicando, em 1816, Travels in Brazil (1992, p. 82-85). Segundo o seu relato, a organização urbana da "(...) vila de Santo Antônio do Recife, comumente chamada Pernambuco, consiste em três bairros ligados por uma ponte (...). Recife, colocada precisamente sobre o arrecife, (...), (é) o primeiro bairro da cidade composto de casas de tijolos, com três, quatro e mesmo cinco andares. 
A ponte que leva a S. Antônio tem uma estrada empedrada nas extremidades. Em cada ponta há uma capelinha (...). A ponte é formada parte de arcos de pedra, parte de madeira e ladeada de pequenas lojas que a tornam tão estreita que dois carros não passam um perto do outro.

S. Antônio, o bairro central, é composto inteiramente de casas altas e de ruas largas, (...). É o principal bairro da cidade. A ponte que liga S. Antônio à Boa Vista é construída inteiramente de madeira. A rua principal de Boa Vista, erguida em terreno antigamente batido no preamar, é formosa e larga. O rio Capibaribe, tão famoso na história pernambucana, deságua num canal entre S. Antônio e Boa Vista (...)."

A expansão da cidade foi sendo feita do continente, da Boa Vista, em direção ao interior, como podemos verificar no relato de Koster (1978, p. 38-39): "Passamos Boa Vista e seguimos por um apertado caminho arenoso, (...) dos dois lados estão as numerosas residências de verão dos abastados habitantes da cidade."

Continuando a trilhar o seu caminho, Koster vislumbrou o rio Capibaribe e, situando-se nas suas margens, observou: "A vista é excessivamente encantadora, casas, árvores, jardins de cada banda. O rio faz a curva adiante e parece perder-se no meio da mata. As canoas indo docemente descem com a maré, e tudo reunido forma um espetáculo delicioso. O rio Capibaribe é navegável todo o ano até Apicucos (....)."

Koster observou também um outro aspecto do rio, que amedronta: as cheias. "O rio transborda para suas margens na estação das chuvas e, às vezes, com grande violência. As terras, através das quais ele passa, são extremamente baixas nessa região, e a inundação é muito temida por estender-se longe e largamente. As choupanas de palha, situadas nas bordas, são sempre carregadas e todos os arredores ficam debaixo d'água." As cheias do Capibaribe eram uma constante na relação do rio com a cidade. Durante o século XIX, têm-se informações de várias cheias que ocorreram.

Desde o final do século XVIII, começaram a surgir nas margens das "várzeas do Capibaribe", sítios e chácaras que foram-se multiplicando no século XIX, modificando o tipo de ocupação nos arredores do Recife. No entanto, ainda existiam nesse período grandes extensões de matas pertencentes a engenhos que ainda não tinham sido loteados para casas de campo (MELLO, 1992, p. 197).

Assim, foram-se instituindo os arrabaldes nesses núcleos habitacionais rurais, tendo de início um caráter sazonal, pois esses sítios e chácaras eram habitados no verão, visando-se ao tratamento das doenças e ao deleite proporcionado pelos banhos de rio. Esses banhos eram compartilhados por todos os habitantes, conforme constatou o inglês Waterton, que esteve em Pernambuco em fins de $1816 .^{5}$

Em 1816, também desembarcou no Recife o francês Tollenare ${ }^{6}$ que, nas suas Notas dominicais (1978, p. 20), relatou as suas impressões sobre a cidade do Recife, a partir da sua "maneira de ver". Referindo-se à parte urbana do Recife, ele teceu comentários sobre os três principais bairros daquele período. O bairro do Recife além de ser o mais movimentado, era o que se apresentava "(...) mais mal edificado e o menos asseado".

Tollenare (1978, p. 34) também se referiu à existência de "cabanas" onde residia a população mais pobre. $\bigcirc$ aparecimento desses aglomerados onde habitava a população mais pobre teve início com a instituição da liberdade de alguns escravos negros e com a extinção de alguns engenhos. Como ressalta Freyre (2000, p. 211), "(...) os casebres e mucambos foram-se levantando, rasteiros, pelas partes baixas e imundas da cidade. Pelos mangues, pelas lamas, pelos alagadiços (....)" (Figura 3).

Outro aspecto da cidade que chamou a atenção de Tollenare foi a ponte entre a ilha de Santo Antônio e a Boa Vista. Segundo a sua descrição, "(...) a ponte que serve de passeio durante 


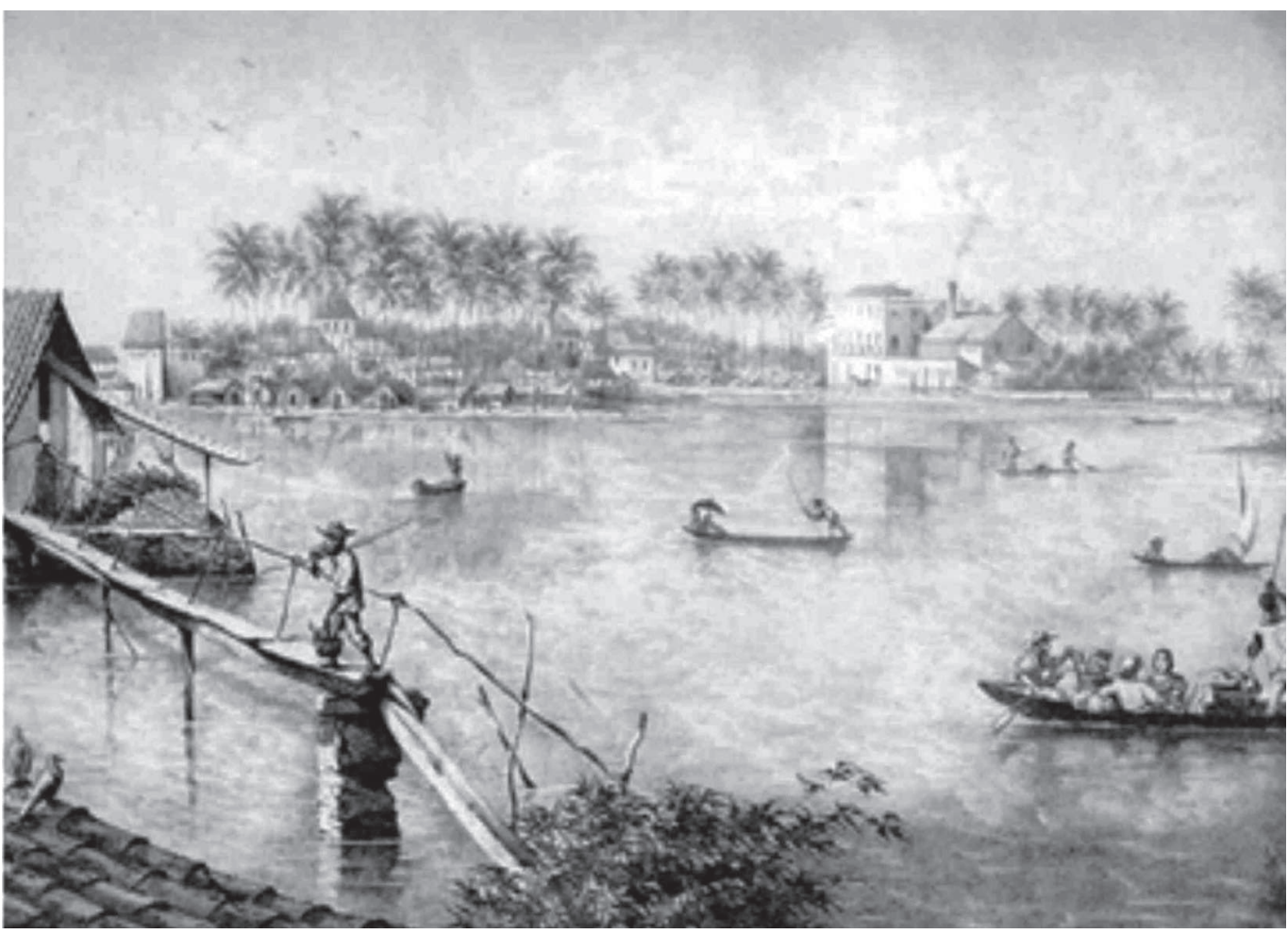

Figura 3

as belas noites deste clima; é guarnecida de bancos. (...) Canoas indígenas, escavadas num só tronco de árvores, conduzidas por negros nus e munidos de compridas varas, cruzam-se em todos os sentidos sobre as águas mansas do rio; (...)."

Nesse período, as duas pontes existentes continuavam sendo as mesmas que foram construídas no período nassoviano. Foram várias as representações sobre as pontes do Recife feitas pelos viajantes,através dos seus relatos, e das iconografias, demonstrando como estão vinculados ao Recife seus rios e suas pontes (Figura 4).

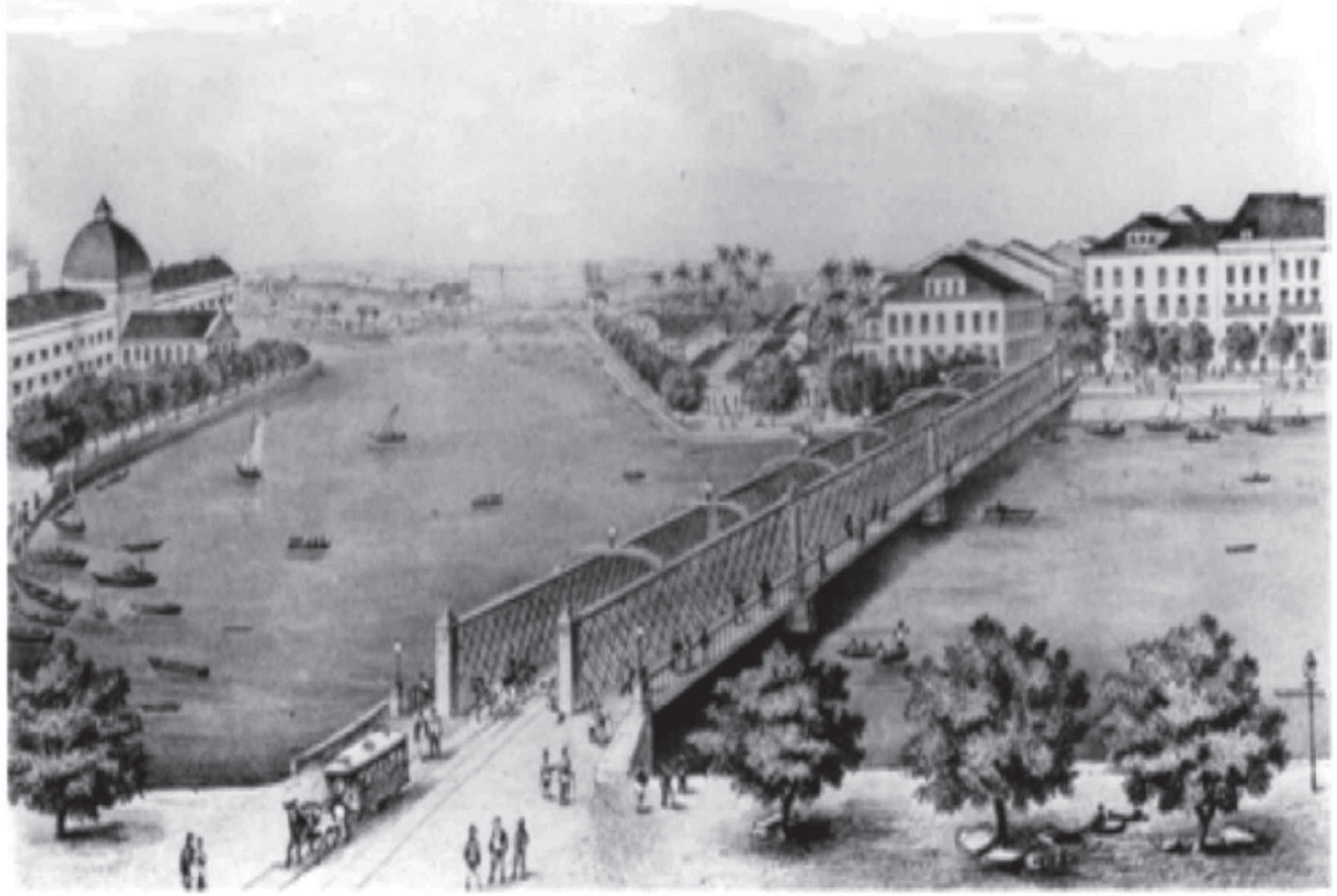


Os arredores do Recife foram relatados por Tollenare de forma prazerosa, enriquecidos com detalhes: "Há em volta da cidade do Recife lindas casas de campo, onde a gente abastada reside de novembro até o começo da quaresma; as mais notáveis estão situadas nas risonhas margens do Capibaribe; a classe média dos habitantes principia também a erguer ali as suas casinhas muito alegres." Tollenare também ressaltou a qualidade da água do rio Capibaribe, constatando que "A limpeza das águas permite ver um fundo de areia pura, que toma um colorido, verde esmeralda escuro, do reflexo da folhagem."

Outro viajante que esteve no Recife em 1819 foi o inglês James Henderson ${ }^{7}$ Esse inglês também destacou alguns aspectos do percurso da Boa Vista, indo em direção aos arredores do Recife. Entre a Boa Vista e a Ponte D'Uchoa, observou elegantes casas brancas, "A cada cem jardas, lugares como esse são encontrados, onde o rio se alarga e apresenta um cenário muito agradável, com a estrada indo por uma curta distância ao longo de sua margem".

Assim, mesmo que o percurso para os arrabaldes fosse feito pelas estradas de terra, vislumbravase, em vários momentos, a paisagem do rio Capibaribe e das suas margens, num prenúncio de que o rio no futuro, prosseguiria banhando os 21 bairros da cidade, estando sempre presente na sua paisagem.

Nesse período, as casas eram construídas com a frente para o rio, cada uma possuindo um cais de atracamento, com as escadas descendo para dar acesso às canoas e aos botes, constituindo o perfil de ocupação da margem esquerda do rio, característico desses arredores no século XIX, como podemos ver nas paisagens retratadas na Figura 5.

A escritora inglesa e artista amadora Maria $\mathrm{Graham}^{8}$, desembarcou da fragata Doris no Recife, em 1821, e apesar de a cidade estar em estado de guerra, visando a independência, ela não deixou de observar a cidade e seus arrabaldes, selecionando os elementos que compunham essa paisagem, atribuindo-Ihes significado.

O olhar do viajante que observa a paisagem, visando posteriormente a narrá-la através de publicações, não é desprovido de ambigüidade. Curvier ${ }^{9}$ dizia ser importante para esse tipo de observador ter a liberdade de observar a natureza e, ao mesmo tempo, controlá-la, para não ser surpreendido por ela. Mas, ao mesmo tempo existia o momento fenomenológico, daquilo que era tocado e visto pelo sujeito. Foi nessa direção que se deu o relato de Maria Graham. Ao atravessar a ponte entre a ilha de Santo Antônio e a Boa Vista, ela ressaltou que não poderia haver "(...) nada mais belo no gênero do que o vivo panorama verde, com o largo rio sinuoso. A vegetação é deliciosa para os olhos ingleses. Não tenho dúvidas que os prados planos e os rios que fluem vagarosamente atraíram particularmente os holandeses, fundadores do Recife" (GRAHAM, 1992, p. 126).

As experiências dos viajantes não eram divulgadas apenas através dos livros publicados, mas também em relatórios oficiais, jornais, revistas e palestras para as comunidades científicas, missionárias ou filantrópicas, entre outras. Nesse sentido, ressalta Lima (2001, p. 48), "(...) a autoridade daquele que falava ou escrevia, mesclava-se ao projeto colonizador ou imperialista; a legitimidade do discurso era garantido pelo papel civilizador do autor, fosse ele missionário, hidrógrafo, naturalista, ou artista".

Foi nessa direção que ocorreu o relato do missionário americano, Daniel Kidder (1972), que esteve no Brasil durante o período de 1836-37 e de 1840-42, visitando o Nordeste, para divulgar sua religião ${ }^{10}$. De acordo com Kidder, Santo Antônio era o bairro mais bonito, tendo em frente ao arsenal do exército, um cais à margem do rio, construído recentemente. "Junto a muralha colocaram bancos para o público. É muito agradável sentar-se aí pela manhã ou a noite (...)." (KIDDER, 1972, p. 79)

O cais era um dos elementos muito presentes nas imagens do Recife, representado na iconografia do século XIX, porque havia uma movimentação fluvial muito intensa, de canoas, jangadas, 
barcos a vela. Os pintores da época retratavam os transeuntes parados observando a fluência do rio (Figura 6). No núcleo urbano, o rio predomina na paisagem até os dias atuais, como também predominava nas paisagens dos arrabaldes naquele período. Como enfatiza Sette (1978, p. 57), "Os cais do Recife revestem-se, de um encanto e de uma sedução experimentada, ao que se vê das velhas gravuras, desde as mais distantes gerações que os palmilharam".
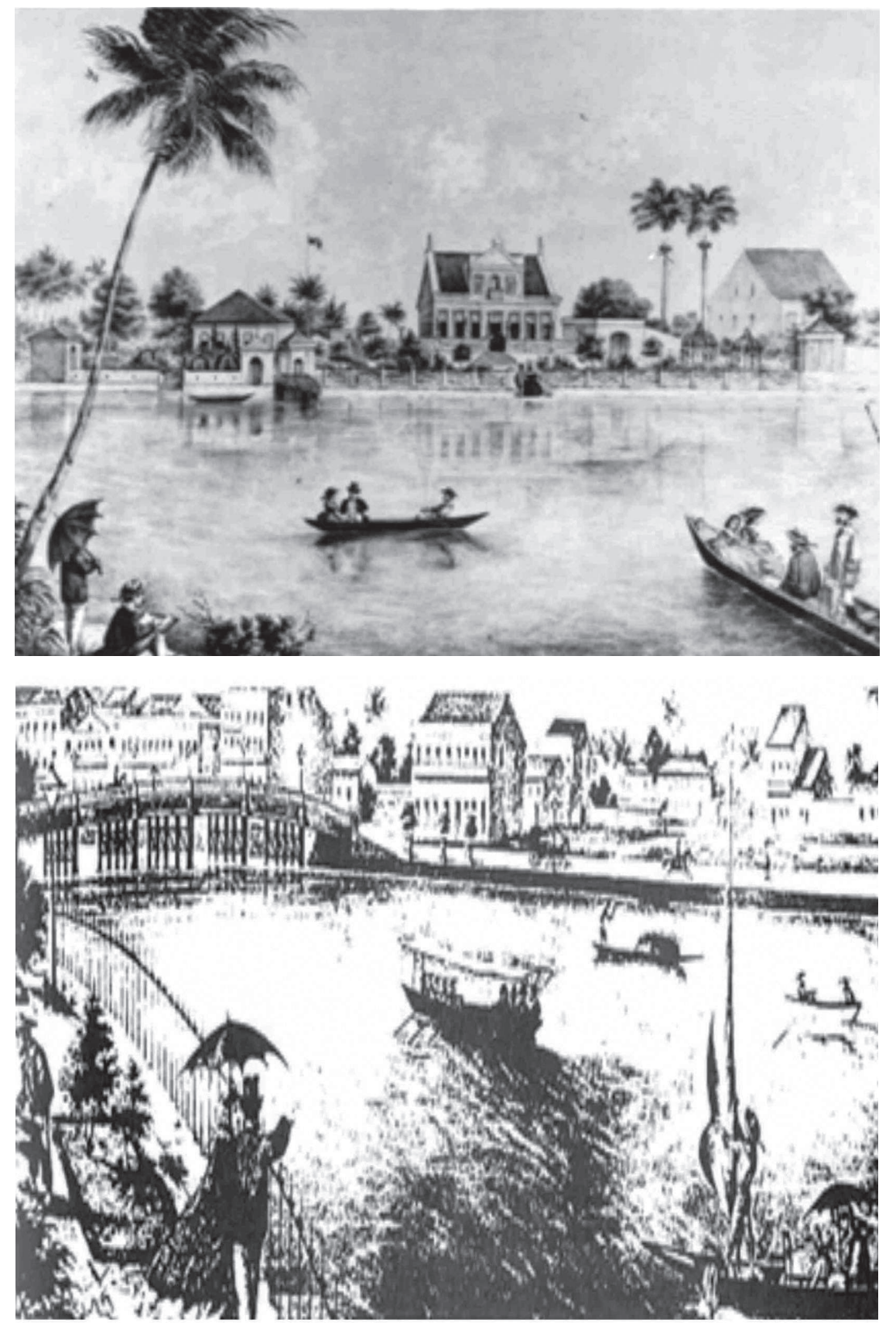

Figura 5

Figura 6

Continuando seu relato, Kidder comentou que o bairro da Boa Vista era ocupado principalmente por residências, casas de campo e alguns edifícios que situavam-se em frente ao rio. Esse já era o prenúncio dos edifícios que foram sendo construídos defronte do rio, com as vias e os cais localizados às suas margens, hoje só existindo parte desse belo conjunto arquitetônico. A imagem desse conjunto foi sendo representada, ao longo do tempo, através da iconografia, atualmente sendo uma das imagens mais presentes nos cartões postais (Figura 7).

A partir da primeira década do século XIX, começaram a ocorrer as maiores transformações na paisagem do Recife. As primeiras mudanças relevantes ocorridas na cidade passaram a ser 


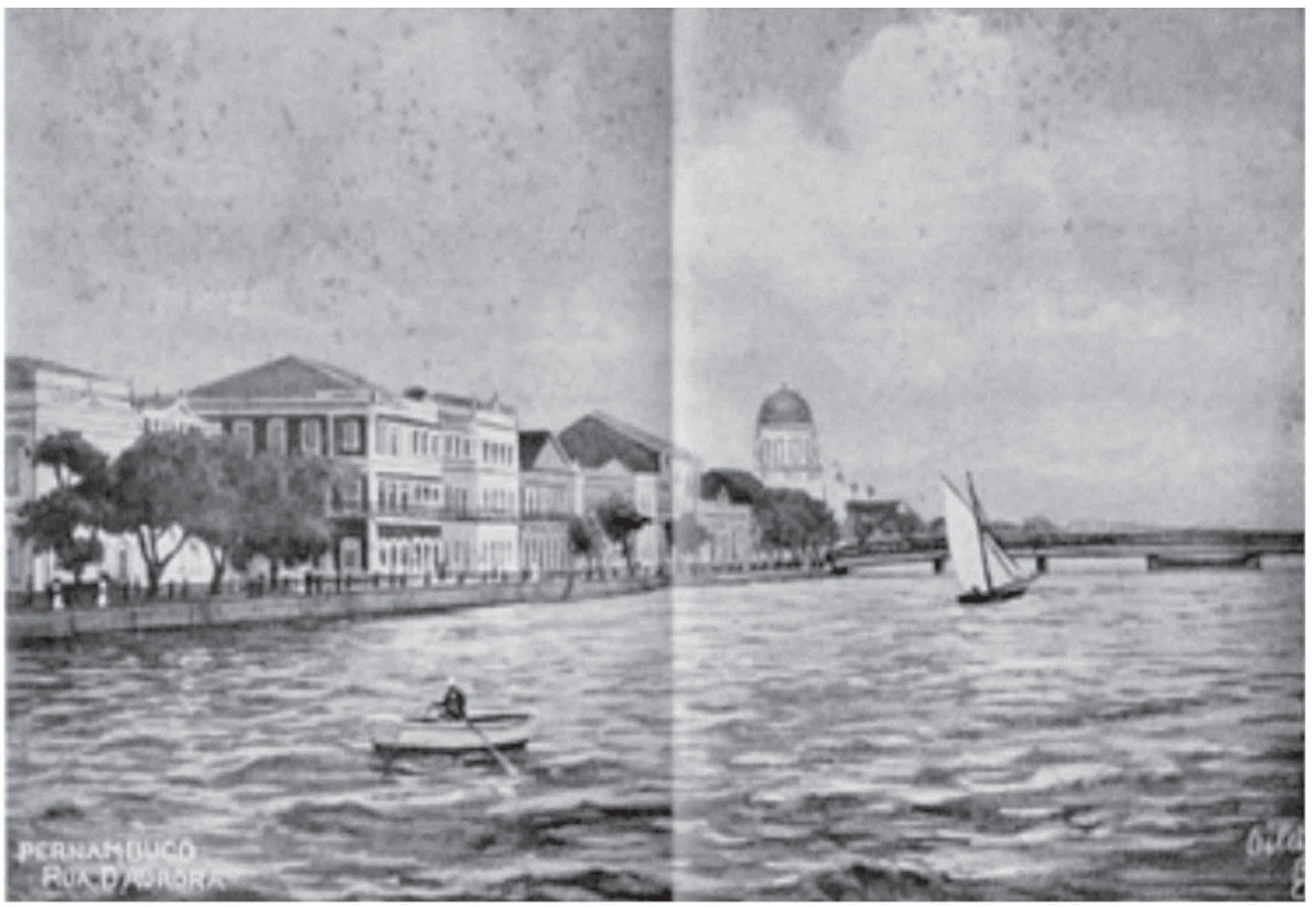

Figura 7

implementadas na gestão de Francisco do Rego Barros, o conde da Boa Vista, que governou Pernambuco entre 1837 e 1845. Tendo estudado na França, o governador convidou para participar da sua administração técnicos e trabalhadores franceses, coordenados por Louis Vauthier, visando a dar um caráter "moderno" à organização urbana da cidade.

Nesse contexto, as propostas de urbanização da cidade foram sendo implementadas, segundo uma "maneira de ver" européia. Nesse sentido, foram construídos às margens do rio Capibaribe, na área urbana, o palácio do Governo, a penitenciária, o teatro Santa Isabel, assim como foram criados passeios públicos, praças e jardins ribeirinhos, incluindo alguns trechos da rua da Aurora e da rua do Sol (Figura 8), tendo como cenário o rio Capibaribe (MESQUITA, 1998, p. 27). E assim o rio foi-se impondo à cidade construída, sem permitir que ela se fechasse a ele, constituindo-se o elemento marcante da paisagem urbana.

Vauthier, ao chegar ao Recife, declarou-se encantado com as "margens do Capibaribe, agrestes e belas"11. Quando dirigiu a Companhia de Obras Públicas, formulou um relatório propondo um sistema de navegação fluvial, comunicando as diversas partes da cidade às localidades vizinhas, uma vez que a mesma era cortada por rios que se dirigiam até a algumas cidades do interior. Ele também sugeriu a canalização de alguns trechos do Capibaribe e recomendou precaução nas mudanças de percurso dos rios, que poderiam prejudicar as futuras retificações (CHACON, 1959, p. 46-80).

Com relação aos serviços de infra-estrutura, foram construídas as pontes da Madalena, de Afogados, de Jaboatão, a ponte pênsil da Caxangá, e foram reformadas a do Recife e a da Boa Vista. Ainda nesse período, começaram a ser feitos grandes investimentos no sistema viário, tanto no núcleo urbano, com a abertura de grandes vias visando ao embelezamento da cidade e ao fluxo de veículos, como na melhoria dos caminhos existentes e na abertura de estradas, facilitando o acesso aos arredores da cidade, possibilitando que algumas famílias passassem a residir e não apenas veranear nos subúrbios.

Esse conjunto de reformas implementadas na administração de Rego Barros deu à cidade uma outra dimensão, como podemos constatar no relato de Ave-Lallemant ${ }^{12}$, em 1859. Ao chegar a Pernambuco, ele constatou ser "uma cidade inteiramente comercial", com uma população de 


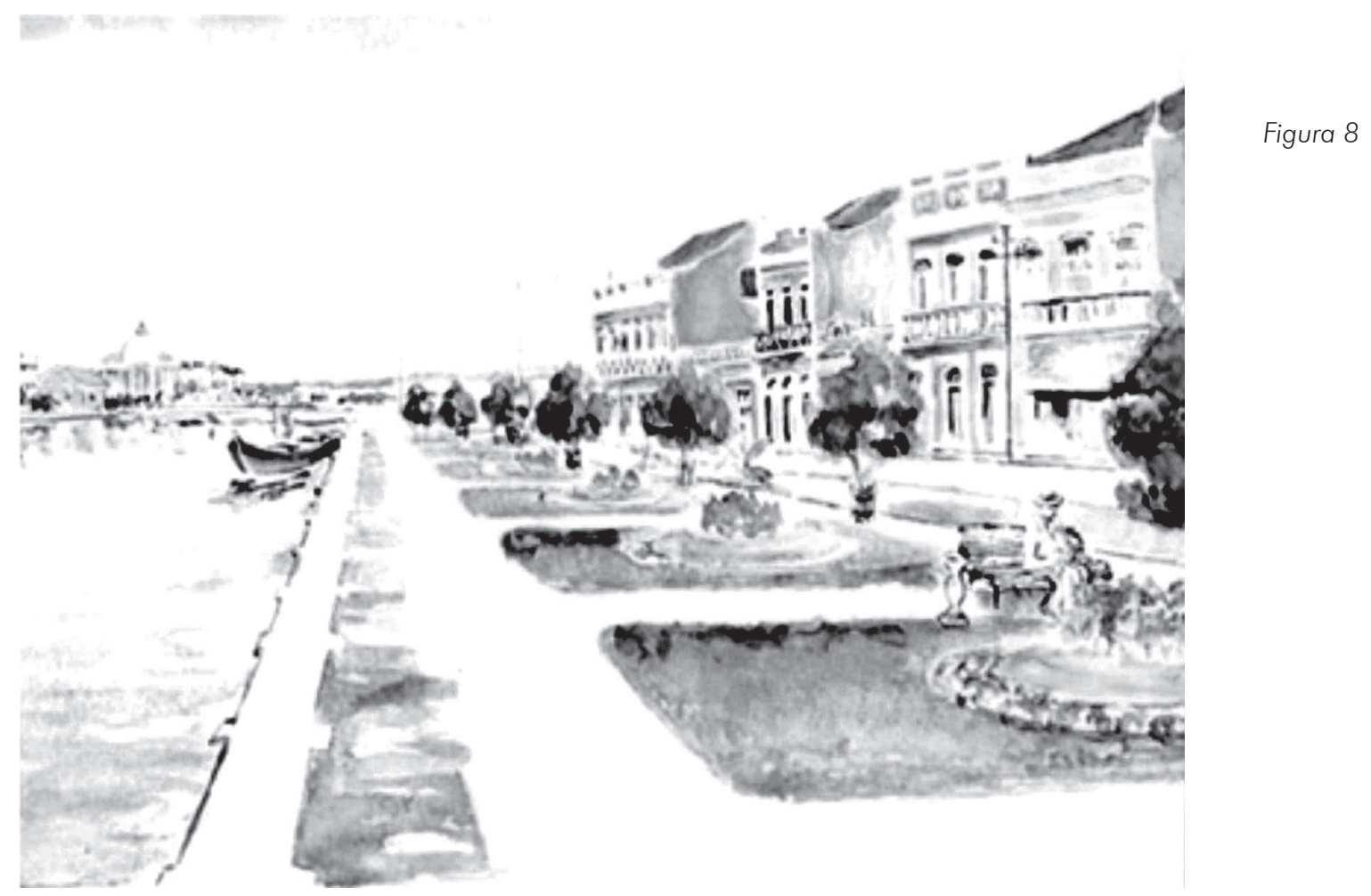

100.000 habitantes. "Ao longo das encantadoras lagunas e no meio da cidade, já começaram a desenvolver-se certa distinção e beleza nas casas e edifícios públicos recém construídos, que um dia farão desta cidade, que surge das águas, uma das mais bonitas do mundo, que nada tem a invejar, nem mesmo de Hamburgo com sua magnífica bacia de Alster."

Muitos dos viajantes que estiveram na cidade do Recife a compararam a cidades européias, sobretudo àquelas em cuja paisagem a água, as pontes e os canais eram um elemento marcante, como Hamburgo, Amsterdã e Veneza. Assim, a paisagem da cidade do Recife foi sendo representada por aqueles que a descreveram e a reinventaram.

Dom Pedro II ${ }^{13}$, ao visitar o Recife, em 1859, imagina a cidade como Veneza, ao observar que "(...) as casas iluminadas sôbre os rios que contornam a ilha de Santo Antônio, dão-lhe o aspecto do que imagino será Veneza".

Recife também foi comparado a um pedaço da Holanda por Teresa, princesa da Baviera ${ }^{14}$, que esteve na cidade em 1888. Segundo seu relato, "Recife e Santo Antônio causou-nos uma impressão muito agradável. Em lugar algum, em todo o país, os vestígios da ocupação holandesa conservam-se de forma tão clara como aqui; É como se um pedaço da Holanda tivesse sido transplantado para o Brasil (...). Casas estreitas e altas, com telhados inclinados (a pique) permitem-nos supor que nos achamos no Norte germânico".

Alguns habitantes representaram o Recife, durante o século XX, recorrendo a comparações com Amsterdã e Veneza. O cientista social Josué de Castro (1992, p. 34), ao se referir à formação da cidade do Recife, ressaltou: "Foi nesses bancos de solo ainda mal consolidados - mistura ainda incerta de terra e de água - que nasceu e cresceu a cidade do Recife, chamada de cidade anfíbia, como Amsterdã e Veneza, porque assenta as massas de sua construção quase dentro d'água, aparecendo numa perspectiva aérea, com seus diferentes bairros, flutuando esquecido à flor das águas."

Joaquim Nabuco ${ }^{15}$, ao representar a cidade do Recife, comparou as suas diferenças e similaridades com Veneza, em uma carta publicada n'O Paiz, no final do século XIX. De acordo com a sua "maneira de ver", "O Recife é com efeito uma Veneza (...) não pelos palácios de mármore 
do grande canal, que mostram, (...), a mais bela fase da arquitetura da Renascença, não por essa praça de S. Marcos, que só tem uma rival no mundo, não pela tradição de máscaras e barcarolas, que flutua sobre as lagunas (...). O Recife não tem nada disso, mas como Veneza é uma cidade que sai da água e que nela se reflete (...). Melhor porém do que em Veneza, os canais do Recife são rios, a cidade sai da água doce e não da maresia das lagunas, o seu horizonte é amplo e descoberto, as suas pontes são compridas como terraços suspensos sobre a água, e o oceano vem se quebrar diante dela em um lençol de espumas por sobre o extenso recife que a guarda como trincheira, genuflexório!".

Ainda no final do século XIX, foram instituídos como norma, determinados locais para o despejo dos dejetos, assim como das águas servidas. Essas normas vieram atender às reclamações estampadas nos jornais da época, com relação ao mal-estar causado por esses despejos, que eram feitos no rio, em locais próximos às estações de passageiros dos trens e das maxambombas, (SETTE, 1981, p. 248). Apesar de os locais de despejo terem sido mudados, os dejetos continuaram sendo jogados ao longo do rio Capibaribe, e somente depois é que foi proibido esta prática.

Com o crescimento da cidade e o seu adensamento, as condições higiênicas foram-se deteriorando, principalmente devido à falta de um sistema de eliminação dos dejetos e das águas servidas. Nesse contexto, diante do desencadeamento das epidemias de febre amarela e cólera morbus, é que foi contratada uma empresa para explorar os serviços de coleta de lixo, escoamento de águas servidas e esgoto. As águas servidas continuaram sendo escoadas para o rio através de canalização.

No final do século XIX, continuariam a ser implementadas as propostas urbanas visando a "modernizar" a cidade do Recife. Nesse período, o Brasil procurava-se inserir no processo de expansão mundial do capitalismo, o que acarretou profundas mudanças na economia nacional e, em conseqüência na economia local. As repercussões dessas mudanças vão-se dar sobretudo nas cidades, com investimentos na modernização da infra-estrutura urbana. Nesse período, o Recife era o pólo comercial da região e não tinha somente a função portuária, embora esta ainda fosse a dominante.

Nesse contexto é que foram sendo direcionadas as reformas urbanas, com a remodelação do porto do Recife, que começou a ser implementada no início do século XX, e os investimentos no sistema viário. As vias foram sendo abertas, tendo como diretriz a ligação do porto com as pontes, com uma distribuição rádio concêntrica, característica marcante na forma de expansão da cidade, ligando-a ao interior, facilitando, assim, o escoamento dos produtos de subsistência que abasteciam a cidade.

Era transportado também por essas vias o açúcar trazido das usinas, localizadas no interior, que começaram a substituir os engenhos. De acordo com Andrade (1966, p. 84), com as usinas, os rios perderam as funções que tinham ao tempo dos engenhos, "como fonte de energia, (e) como força motriz", e começou o processo de polvição, pois os usineiros passaram a lançar nos mesmos a calda da cana. A partir daí, as relações entre o homem e a água começaram a modificar-se drasticamente, pois, até então, mesmo que não houvesse o devido respeito a esses recursos hídricos, ele não os polvía na mesma proporção que passou a fazer.

Com a abertura das estradas e a comodidade dos meios de comunicação, as casas passaram a ser construídas com a frente para essas vias, nos arrabaldes, apesar de não serem abandonados os acessos para o rio, pois ele ainda oferecia como vantagem o transporte de canoa e o banho como lazer ou higiene. No entanto, o lado da estrada foi paulatinamente se impondo como o lado nobre, com a frente das casas se voltando para ela e o lado do rio foi tornandose os fundos das casas. A partir desse período, começou a ser paulatinamente desarticulado o sistema de transporte fluvial (MILFONT, 2003). 
No final do século XIX, a cidade do Recife já não tinha feições tão provincianas como no início do século. Como ressalta Menezes (1978, p. 260), "O século XIX será, na verdade, o grande século do Recife. Veremos o seu crescimento, mas também assistiremos o seu caminhar lento para a destruição que se processará nos seus últimos anos com as obras do porto".

\section{Considerações finais}

No percurso feito, pôde ser interpretado com base nos relatos dos viajantes e nas iconografias, que são registros "simbólicos" de grande valor na representação das paisagens (COSGROVE, 1993, p. 8), tanto os significados das paisagens do Recife e do rio Capibaribe para esses viajantes, como a importância desse rio na formação histórica das paisagens dessa cidade.

Durante este trajeto a formação dessas paisagens passou a ter outra dimensão, pautada em uma ação modernizadora, de acordo com os preceitos urbanos e a "moda" européia adotados nessa época. Nesse contexto, foram criadas novas paisagens urbanas, centradas na construção de edifícios e passeios públicos, cais e jardins ribeirinhos, tendo como cenário o rio Capibaribe, que passou a se impor à paisagem construída.

Essa breve narrativa pretende contribuir para a compreensão sobre a formação histórica das paisagens da cidade do Recife e do rio Capibaribe, sob o enfoque das representações e dos significados. Através dessa narrativa pudemos constatar como o rio está vinculado a história da cidade, integrando-se à sua paisagem. As recordações e os significados daquele momento histórico foram sendo incorporados nos dias atuais, pelo recifense, que escolheram o rio Capibaribe e as suas pontes como símbolo da cidade do Recife. Assim, para se compreender as expressões manifestadas por uma cultura em sua paisagem é necessário conhecer o significado que têm as paisagens para essa cultura. Através desse entendimento poderão ser identificados os elementos simbólicos que caracterizam as paisagens, visando a conservação das mesmas, pois estes constituem patrimônios culturais, que fazem parte da memória local.

\section{Notas}

(1) Texto baseado na tese de doutorado, intitulada Um recorte da paisagem do rio Capibaribe: Seus significados e representações, apresentada no Programa de Pós-Graduação em Geografia, em 2003.

(2) Cidade flúvio-marinha, capital do estado de Pernambuco, está situada entre $8^{\circ} 04^{\prime} 00^{\prime \prime}$ de latitude sul e $43^{\circ} 52^{\prime} 00^{\prime \prime}$ de latitude oeste (GOMES,1997, p. 58).

(3) A narrativa é um método utilizado pelos geógrafos que estudam a paisagem cultural, para interpretar os significados da paisagem, a partir de suas representações, baseado em uma referência empírica, e, no caso deste estudo, baseia-se nos relatos dos viajantes que estiveram na cidade do Recife no século XIX.

(4) Henry Koster veio ao Recife para tratamento de uma tuberculose, permanecendo aqui por um longo tempo. Foi bom observador e anotou o que via: os costumes, o povo, os detalhes da cidade, e publicou em Londres, em 1816, Travels in Brazil (MAIOR; SILVA, 1992, p. 78).

(5) Apud MELLO (1992, p. 270).

(6) Tollenare permaneceu no Recife nos anos de 1816 e1817, dedicando-se ao comércio de algodão, embora fosse interessado em botânica, costumando escrever suas notas aos domingos (MAIOR; SILVA, 1992, p. 90).

(7) Autor do livro sobre o Brasil A history of the Brazil: Comprising its geography, commerce, colonization, aboriginal inhabitants (1992, p. 105-119).

(8) Maria Graham veio ao Recife acompanhando seu marido, o capitão Thomas Graham, comandante da fragata Doris (MAIOR; SILVA, 1992, p. 122).

(9) Apud LIMA (2001, p. 46).

(10) Em 1845, publicou nos Estados Unidos o livro Brazil and the brazilians portrayed in historical and descritive sketches. A obra sobre o Brasil mais conhecida naquele país: (MAIOR; SILVA, 1992, p. 149).

(11) Apud CHACON (1959, p. 80). 
(12) Apud CAVALCANTI (1978, p. 271).

(13) Apud AULER (1975, p. 361).

(14) Apud JUREMA (1971, p. 98).

(15) Apud SETTE (1978, p. 63).

\section{Bibliografia}

ANDRADE, Manuel Correia. Polvição dos cursos d'água da zona da mata de Pernambuco, pelo despejo de resíduos e águas servidas pelas indústrias. O Boletim. Recife: Instituto Joaquim Nabuco de Pesquisas Sociais, n. 15, 1966.

AULER, Gaspar. Dom Pedro II - Viagem a Pernambuco (em 1859). Revista do Arquivo Público do Estado de Pernambuco, Receife, v. XXI , n. 31, 1975.

CASTRO, Josué. Visões do Recife. In: MAIOR, M. S.; SILVA, L. D. (Org.) O Recife: Quatro séculos de sua paisagem. Recife: FUNDAJ/Massangana/PCR, 1992. p. 253-260.

CAVALCANTI, Vanildo Bezerra. O Recife e a origem dos seus bairros centrais. In: $O$ tempo do Recife. Arquivo público estadual de Pernambuco. Recife: Editora Universitária, 1978. p. 222-252.

CHACON, Valmireh. O Capibaribe e o Recife. História social e sentimental de um rio. Recife: Secretaria de Educação e Cultura de Pernambuco/UFPE, 1959.

COSGROVE, Denis. On the reinvention of cultural geography by Price and Lewis: Commentary. In: Annals of Association of american geographers, v. 83, n. 3, 1993. p. 515-517.

FREYRE, Gilberto. Sobrados e mocambos. Rio de Janeiro/São Paulo: Editora Record, 2000.

GOMES, Edvânia Torres Aguiar. Recortes de paisagens na cidade do Recife - Uma abordagem geográfica. 1997. 290 p. Tese (Doutorado) - Departamento de Geografia Universidade de São Paulo, São Paulo, 1997.

GRAHAM, M. O Recife em tempo de revolução. In: MAIOR, M. S.; SILVA, L. D. (Org.) O Recife: Quatro séculos de sua paisagem. Recife: FUNDAJ/Massangana/PCR, 1992. p.121-142.

JUREMA, Aderbal. O sobrado na paisagem recifense. Recife: UFPE, 1971.

KIDDER, Daniel. Reminiscências de viagens e permanências no Brasil (Províncias do Norte). São Paulo: Biblioteca Histórica Brasileira/Martins Fontes/Edusp, 1972.

LIMA, Lúcia. O Rio de Janeiro dos viajantes: O olhar britânico (1800-1850). Rio de Janeiro: Jorge Zahar Editor, 2001.

MAIOR, M. S.; SILVA, L. D. O Recife: Quatro séculos de sua paisagem. Recife: Fundaj/Massangana/PCR, 1992.

MELLO, Evaldo Cabral. Canoas do Recife. Recife: FUNDAJ/Massangana, 1987.

MELLO, José Antônio Gonçalves. Capunga: Crônica de um bairro recifense. In: MAIOR, M.S.; SILVA, L. D. (Org.) O Recife: Quatro séculos de sua paisagem. Recife: FUNDAJ/Massangana/PCR, 1992. p. 263-281.

MELO, Vera Mayrinck. Um recorte da paisagem do rio Capibaribe: Seus significados e representações. 2003. 273 p. Tese (Doutorado) - Programa de Pós-Graduação em Geografia, Universidade Federal do Rio de Janeiro, Rio de Janeiro, 2003.

MENEZES, José Luís Mota. $\bigcirc$ Recife e sua arquitetura. In: Um tempo do Recife. Recife: Editora Universitária, 1978.

MESQUITA, Liana. Memória dos verdes urbanos do Recife. Cadernos do Meio Ambiente do Recife, Recife, v. 1, n. 1, p. 11-57, 1998.

MILFONT, Magna. Caminhos e marcas na cidade: A influência do transporte fluvial nos rios e mares do Recife, no século XIX. In: PONTUAL, V.; CARNEIRO, A. R. (Org.) História e paisagem: Ensaios urbanísticos de São Luís e do Recife. Recife: Edições Bagaço, 2005.

SETTE, Mário. Arruar: História pitoresca do Recife antigo. Recife: Governo do Estado de Pernambuco, Secretaria Estadual da Cultura, v. XII, 1978 (Coleção Pernambucana).

Maxambombas e maracatus. Recife: Fundação de Cultura da Cidade do Recife, 1981

TOlLenARE, L. F. Notas dominicais. Recife: Governo do Estado de Pernambuco, Secretaria de Cultura, Depto. de Cultura, v. XVI, 1978 (Coleção Pernambucana). 